\title{
Assessment of Soil Fertility and Crop Nutrient Status in Agricultural Soils Near a Brick Kiln Cluster
}

\author{
Nasrin Chowdhury ${ }^{1} \&$ Md. Mamunur Rasid ${ }^{1}$ \\ ${ }^{1}$ Department of Soil Science, Faculty of Biological Sciences, University of Chittagong, Chattogram, Bangladesh \\ Correspondence: Nasrin Chowdhury, Department of Soil Science, Faculty of Biological Sciences, University of \\ Chittagong, Chittagong University Road, 4331, Chattogram, Bangladesh. Tel: 88-017-1209-2115. E-mail: \\ nasrin@cu.ac.bd
}

Received: October 23, 2020

Accepted: November 22, $2020 \quad$ Online Published: December 15, 2020

doi:10.5539/jas.v13n1p122

URL: https://doi.org/10.5539/jas.v13n1p122

The research is financed by University Grants Commission, Bangladesh.

\begin{abstract}
Brick kiln exhaust when deposited can hamper the nutritional status of the agricultural soils and crops. To study the impact, soil and associated plant samples were collected from the vicinity of a brick kiln cluster in Chattogram, Bangladesh. The soil contamination was evaluated by heavy metal indices. Agricultural soils close to the brick kiln area were very strongly acid to slightly acid. Organic carbon, total nitrogen and available phosphorus content of the agriculture soils near brick kiln cluster were $0.35 \%$ to $1.01 \%, 0.10$ to $0.24 \%$ and 2.21 to $13.48 \mathrm{mg} \mathrm{kg}^{-1}$ respectively and the significant different mean value of $0.70 \%, 0.22 \%$ and $14.65 \mathrm{mg} \mathrm{kg}^{-1}$ respectively in the reference soil. The nutritional status of sampling sites was lower than the previously reported data. The nutrition status of the plants was at an optimum level as regular fertilizer application was practiced but showed an irregular pattern along with all the soil parameters and heavy metal indices. The contamination factor $\left(C_{d}\right)$, potential ecological risk index $(P E R)$ and geo-accumulation index $\left(I_{g e o}\right)$ demonstrated that the agricultural soils in the vicinity of the brick kiln cluster were moderately- to highly-polluted. This indicates the deterioration of soil quality by uncontrolled brick kiln operation.
\end{abstract}

Keywords: agriculture, contamination factor, geo-accumulation index, heavy metals, potential ecological risk index, principal component analysis

\section{Introduction}

One of the key factors for the development of a country is industrialization but it accelerates the process of environmental degradation. Air pollution and land degradation from brick kiln's emission is common in developing countries which adversely affecting the environment of its surroundings (Rahman, Awan, Hassan, \& Khattak, 2000; Bhanarkar, Gajghate, \& Hasan, 2002; Skinder, Pandit, Sheikh, \& Ganai, 2014). The brick kiln exhaust not only contributes significantly to air pollution but also cause a reduction of crop yield (Sharma, 2000), poor vegetation growth as well as soil degradation and reduction of microbial activity (Hossain, Zahid, Arifunnahar, \& Siddique, 2019; Khan et al., 2007a). The burning of enormous C and N in brick kiln degrades the soils and poses a threat to the environment by provoking atmospheric pollution and climate change (Khan et al., 2007b). In the agricultural soil of the brick kiln area, the concentrations of $\mathrm{Cd}$ and $\mathrm{Pb}$ were found to be more than the regulatory standards imposed by the US Environmental Protection Agency (Ismail et al., 2012; Ravankhah, Mirzaei, \& Masoum, 2017).

In the case of inducing concern, the large brick kiln clusters, located in the vicinity of large brick demand centers are paramount. The local impact of pollution caused by small isolated brick kilns located in rural areas is insignificant. A plethora of information is available for heavy metal pollution in agricultural soils of Bangladesh, where some studies focused on heavy metal contamination through aerial deposition by heavy traffic. However, no detailed study on the nutritional status in agricultural soil concerning pollution impact on plant nutrients from brick kiln cluster has been conducted yet. Several huge clusters of brick kiln are present in Hathazari, Chattogram which can be an important source of $\mathrm{Cd}$ and $\mathrm{Pb}$ toxicity with the potential to harm the ecology of the surrounding agricultural soil. Natural hill resources especially soil and tree biomass are under threat from soil 
thief for brick production. Soil degradation and environmental pollution are not inexorable but can be controlled if they are regularly monitored, major exploitation are controlled and modern techniques of highly efficient machines are evolved. With this background, the objectives of this study were to evaluate the possible impact of a brick kiln cluster on soil and plant nutrient status through the quantification and comparison with the ambient agricultural soils of the unaffected area and published data.

\section{Method}

\subsection{Study Area and Soil and Plant Sampling}

A cluster of the brick kiln was selected which was surrounded by the agricultural field in Hathazari, Chittagong district, Bangladesh. The sampling from the study area was carried out from October, 2018 to March, 2019 which is the operation season of brick kilns in Bangladesh depending on the monsoonal rains. Brick kiln fumes are the major source of air pollution during these dry seasons. The sampling locations were systematically set based on crops growing and distance from the brick kiln cluster (A-F) (Table 1). At these locations, three different crop fields were selected and three soil subsamples were collected from each site. The reference site (R) was the agricultural soils approximately $2.5 \mathrm{~km}$ far from site A. Soil samples were collected from the soil surface to the root zone $(0-30 \mathrm{~cm})$. Wind flow direction was considered for the effect of fly ash deposition on vegetation and soil. Plant samples were also collected from the respective soil sampling sites (agricultural fields).

Table 1. Locations, site legend and physical properties (mean $\pm \mathrm{SD}$ ) of agricultural soils adjacent to the brick kiln cluster

\begin{tabular}{|c|c|c|c|c|c|c|c|c|c|c|}
\hline \multirow{2}{*}{$\begin{array}{l}\text { Sampling } \\
\text { location }\end{array}$} & \multirow{2}{*}{$\begin{array}{l}\text { Legend for } \\
\text { sampling sites }\end{array}$} & \multicolumn{2}{|c|}{ Geographical Coordinate } & \multirow{2}{*}{ Crop plants } & \multirow{2}{*}{ Soil Texture } & \multirow{2}{*}{\multicolumn{2}{|c|}{$\begin{array}{l}\text { Sand } \quad \text { Silt } \\
---0 .\end{array}$}} & \multirow{2}{*}{ Clay } & \multirow{2}{*}{$\begin{array}{l}\mathrm{BD} \\
\mathrm{g} \mathrm{cm}^{-1} \\
\end{array}$} & \multirow{2}{*}{$\begin{array}{l}\text { WHC } \\
\%\end{array}$} \\
\hline & & Latitude & Longitude & & & & & & & \\
\hline \multicolumn{11}{|c|}{ Crop fields near brick kiln cluster } \\
\hline & $\mathrm{CP} 1$ & $22^{\circ} 32^{\prime} 15.33^{\prime \prime} \mathrm{N}$ & $91^{\circ} 46^{\prime} 51.10^{\prime \prime} \mathrm{E}$ & Solanum tuberosum & Sandy clay loam & $53.83^{\mathrm{e}}$ & $23.34^{\mathrm{c}}$ & $22.82^{\mathrm{a}}$ & $1.48^{\mathrm{j}}$ & $43.53^{\mathrm{i}}$ \\
\hline \multirow[t]{3}{*}{ A } & $\mathrm{CP} 2$ & $22^{\circ} 32^{\prime} 17.58^{\prime \prime} \mathrm{N}$ & $91^{\circ} 46^{\prime} 51.98^{\prime \prime} \mathrm{E}$ & Artemisia vulgaris & Sandy clay loam & $49.66^{\mathrm{c}}$ & $22.63^{\mathrm{bc}}$ & $27.71^{\mathrm{c}}$ & $1.39^{\mathrm{abc}}$ & $50.40^{\mathrm{m}}$ \\
\hline & $\mathrm{CP} 3$ & $22^{\circ} 32^{\prime} 17.16^{\prime \prime} \mathrm{N}$ & $91^{\circ} 46^{\prime} 49.66^{\prime \prime} \mathrm{E}$ & Ipomoea batatas & Sandy clay loam & $49.55^{\mathrm{c}}$ & $26.53^{\text {defg }}$ & $23.92^{\mathrm{ab}}$ & $1.38^{\mathrm{ab}}$ & $52.82^{\mathrm{q}}$ \\
\hline & $\mathrm{CP} 4$ & $22^{\circ} 32^{\prime} 0.36^{\prime \prime} \mathrm{N}$ & $91^{\circ} 47^{\prime} 2.47^{\prime \prime} \mathrm{E}$ & Capsicum species & Sandy clay loam & $49.73^{\mathrm{c}-}$ & $26.02^{\text {def }}$ & $24.25^{5 \mathrm{~b}}$ & $1.39^{\mathrm{abc}}$ & $37.74^{\mathrm{d}}$ \\
\hline \multirow[t]{3}{*}{ B } & CP5 & $22^{\circ} 32^{\prime} 0.37^{\prime \prime} \mathrm{N}$ & $91^{\circ} 47^{\prime} 4.71^{\prime \prime} \mathrm{E}$ & Oryza sativa & Sandy clay loam & $48.87^{\mathrm{c}}$ & $20.47^{\mathrm{a}}$ & $30.67^{d}$ & $1.38^{\mathrm{a}}$ & $49.66^{\mathrm{j}}$ \\
\hline & CP6 & $22^{\circ} 32^{\prime} 1.02^{\prime \prime} \mathrm{N}$ & $91^{\circ} 47^{\prime} 7.08^{\prime \prime} \mathrm{E}$ & Solanum tuberosum & Sandy clay loam & $52.16^{\mathrm{d}}$ & $25.00^{\mathrm{d}}$ & $22.84^{\mathrm{a}}$ & $1.48^{\mathrm{j}}$ & $40.34^{\mathrm{g}}$ \\
\hline & CP7 & $22^{\circ} 32^{\prime} 35.02^{\prime \prime} \mathrm{N}$ & $91^{\circ} 46^{\prime} 56.82^{\prime \prime} \mathrm{E}$ & Oryza sativa & Sandy clay loam & $46.13^{\mathrm{ab}-}$ & $19.73^{\mathrm{a}}$ & $34.13^{\mathrm{e}}$ & $1.41^{\mathrm{de}}$ & $39.35^{\mathrm{e}}$ \\
\hline \multirow[t]{3}{*}{$\mathrm{C}$} & СР8 & $22^{\circ} 32^{\prime} 33.76^{\prime \prime} \mathrm{N}$ & $91^{\circ} 46^{\prime} 57.44^{\prime \prime} \mathrm{E}$ & Trichosanthes anguina & Sandy clay loam & $49.99^{\mathrm{c}}$ & $22.68^{\mathrm{bc}}$ & $27.33^{\mathrm{c}}$ & $1.47^{\mathrm{ij}}$ & $40.82^{\mathrm{h}}$ \\
\hline & $\mathrm{CP9}$ & $22^{\circ} 32^{\prime} 34.28^{\prime \prime} \mathrm{N}$ & $91^{\circ} 46^{\prime} 59.85^{\prime \prime} \mathrm{E}$ & Raphanus sativus & Sandy clay loam & $47.00^{\mathrm{ab}}$ & $20.17^{\mathrm{a}}$ & $32.83^{\mathrm{de}}$ & $1.38^{\mathrm{a}}$ & $51.19^{\circ}$ \\
\hline & CP10 & $22^{\circ} 32^{\prime} 49.48^{\prime \prime} \mathrm{N}$ & $91^{\circ} 47^{\prime} 15.71^{\prime \prime} \mathrm{E}$ & Oryza sativa & Sandy clay loam & $45.32^{\mathrm{a}}$ & $22.33^{\mathrm{bc}}$ & $32.35^{\mathrm{de}}$ & $1.44^{\mathrm{g}}$ & $53.10^{\mathrm{r}}$ \\
\hline \multirow[t]{3}{*}{$\mathrm{D}$} & CP11 & $22^{\circ} 32^{\prime} 50.25^{\prime \prime} \mathrm{N}$ & $91^{\circ} 47^{\prime} 10.83^{\prime \prime} \mathrm{E}$ & Brassica nigra & Sandy clay loam & $49.38^{\mathrm{c}}$ & $27.80^{\mathrm{fg}}$ & $22.82^{\mathrm{a}}$ & $1.42^{\mathrm{e}}$ & $49.76^{\mathrm{k}}$ \\
\hline & CP12 & $22^{\circ} 32^{\prime} 47.26^{\prime \prime} \mathrm{N}$ & $91^{\circ} 47^{\prime} 16.43^{\prime \prime} \mathrm{E}$ & Capsicum species & Sandy clay loam & $47.12^{\mathrm{b}}$ & $25.13^{\mathrm{d}}$ & $27.74^{\mathrm{c}}$ & $1.39^{\mathrm{bcd}}$ & $50.81^{\mathrm{n}}$ \\
\hline & CP13 & $22^{\circ} 32^{\prime} 2.60^{\prime \prime} \mathrm{N}$ & $91^{\circ} 47^{\prime} 25.55^{\prime \prime} \mathrm{E}$ & Capsicum species & Sandy clay loam & $49.65^{\mathrm{c}}$ & $27.40^{\mathrm{fg}}$ & $22.95^{\mathrm{a}}$ & $1.47^{\mathrm{ij}}$ & $39.81^{\mathrm{f}}$ \\
\hline \multirow[t]{3}{*}{ E } & CP14 & $22^{\circ} 32^{\prime} 1.44^{\prime \prime} \mathrm{N}$ & $91^{\circ} 47^{\prime} 26.56^{\prime \prime} \mathrm{E}$ & Artemisia vulgaris & Sandy clay loam & $45.73^{\mathrm{ab}}$ & $31.63^{\mathrm{h}}$ & $22.63^{\mathrm{a}}$ & $1.43^{\mathrm{f}}$ & $40.82^{\mathrm{h}}$ \\
\hline & $\mathrm{CP} 15$ & $22^{\circ} 32^{\prime} 3.06^{\prime \prime} \mathrm{N}$ & $91^{\circ} 47^{\prime} 30.38^{\prime \prime} \mathrm{E}$ & Raphanus sativus & Sandy clay loam & $45.50^{\mathrm{ab}}$ & $27.48^{\mathrm{fg}}$ & $27.02^{\mathrm{c}}$ & $1.47^{\mathrm{hij}}$ & $49.66^{\mathrm{j}}$ \\
\hline & $\mathrm{CP} 16$ & $22^{\circ} 32^{\prime} 35.20^{\prime \prime} \mathrm{N}$ & $91^{\circ} 47^{\prime} 27.24^{\prime \prime} \mathrm{E}$ & Artemisia vulgaris & Sandy clay loam & $47.10^{\mathrm{b}^{--}}$ & $30.27^{\mathrm{h}^{-}}$ & $22.63^{\mathrm{a}}$ & $1.47^{\mathrm{hij}}$ & $31.98^{\mathrm{a}}$ \\
\hline \multirow[t]{2}{*}{$\mathrm{F}$} & CP17 & $22^{\circ} 32^{\prime} 31.54^{\prime \prime} \mathrm{N}$ & $91^{\circ} 47^{\prime} 28.95^{\prime \prime} \mathrm{E}$ & Solanum lycopersicum & Sandy clay loam & $50.00^{\mathrm{c}}$ & $27.37^{\mathrm{fg}}$ & $22.63^{\mathrm{a}}$ & $1.47^{\mathrm{hi}}$ & $35.59^{\mathrm{b}}$ \\
\hline & CP18 & $22^{\circ} 32^{\prime} 34.08^{\prime \prime} \mathrm{N}$ & $91^{\circ} 47^{\prime} 30.32^{\prime \prime} \mathrm{E}$ & Brassica nigra & Sandy clay loam & $49.17^{\mathrm{c}}$ & $28.33^{\mathrm{g}}$ & $22.51^{\mathrm{a}}$ & $1.45^{\mathrm{gh}}$ & $35.76^{\mathrm{C}}$ \\
\hline \multicolumn{11}{|c|}{ Reference sites } \\
\hline \multirow{3}{*}{$\mathrm{R}$} & CP19 & $22^{\circ} 32^{\prime} 19.90^{\prime \prime} \mathrm{N}$ & $91^{\circ} 48^{\prime} 20.71^{\prime \prime} \mathrm{E}$ & Oryza sativa & Sandy clay loam & $46.57^{\mathrm{ab}}$ & $25.53^{\mathrm{de}}$ & $27.90^{c}$ & $1.39^{\mathrm{abc}}$ & $52.40^{\mathrm{p}}$ \\
\hline & $\mathrm{CP} 20$ & $22^{\circ} 32^{\prime} 17.01^{\prime \prime} \mathrm{N}$ & $91^{\circ} 48^{\prime} 22.38^{\prime \prime} \mathrm{E}$ & Solanum tuberosum & Sandy clay loam & $46.67^{\mathrm{ab}}$ & $27.13^{\mathrm{efg}}$ & $26.20^{\mathrm{bc}}$ & $1.40^{\mathrm{cd}}$ & $50.37^{1}$ \\
\hline & $\mathrm{CP} 21$ & $22^{\circ} 32^{\prime} 20.62^{\prime \prime} \mathrm{N}$ & $91^{\circ} 48^{\prime} 27.99^{\prime \prime} \mathrm{E}$ & Vigna mungo & Sandy clay loam & $47.00^{\mathrm{ab}}$ & $20.97^{\mathrm{ab}}$ & $32.03^{\mathrm{de}}$ & $1.38^{\mathrm{ab}}$ & $53.65^{\mathrm{s}}$ \\
\hline \multicolumn{11}{|c|}{ Average data of study sites and reference sites } \\
\hline \multirow{2}{*}{\multicolumn{5}{|c|}{$\begin{array}{l}\text { Soils of crop fields near brick kiln cluster } \\
\text { Reference soils }\end{array}$}} & Sandy clay loam & $48.66^{\mathrm{x}}$ & $25.24^{\mathrm{x}}$ & $26.10^{\mathrm{x}}$ & $1.43^{\mathrm{x}}$ & $44.07^{\mathrm{x}}$ \\
\hline & & & & & Sandy clay loam & $46.74^{\mathrm{y}}$ & $24.55^{\mathrm{x}}$ & $28.71^{\mathrm{x}}$ & $1.39^{y}$ & $52.14^{\mathrm{y}}$ \\
\hline
\end{tabular}

Note. Values in the same column followed by the same letter(s) are not significantly different at $p<0.05$ according to ANOVA.

$\mathrm{BD}=$ bulk density; $\mathrm{WHC}=$ water holding capacity.

\subsection{Processing of Samples}

The collected soil samples were stored in the field moist conditions in marked polyethylene bags and immediately taken for laboratory analysis. All soils were separately sieved $(2 \mathrm{~mm})$ after air drying. Plant samples were processed according to the standard procedure. 


\subsection{Analyses}

Particle size distributions were determined by the Hydrometer method (Day, 1965). Textural classes were determined using a triangular coordinate diagram by the USDA soil texture calculator. The $\mathrm{pH}$ of the soil samples was determined in the laboratory (dry soil and distilled water ratio of 1:5) and measured by using a Corning glass electrode $\mathrm{pH}$ meter (Jackson, 1973). The organic carbon (OC) content of the soil samples was determined volumetrically by the wet oxidation method with a $1 \mathrm{~N} \mathrm{~K}_{2} \mathrm{Cr}_{2} \mathrm{O}_{7}$ solution and concentrated $\mathrm{H}_{2} \mathrm{SO}_{4}$ mixture, followed by rapid titration with a $1 \mathrm{~N} \mathrm{FeSO}_{4}$ solution, as recommended by Nelson and Sommers (1983). Total nitrogen (TN) content in soil was determined by the Micro Kjeldahl method following $\mathrm{H}_{2} \mathrm{SO}_{4}$ acid digestion and alkali distillation (Jackson, 1973). Available phosphorus (AvP) of soil was extracted with Bray and Kurtz-1 solution (Bray \& Kurtz, 1945). Phosphorus in the soil extracts was determined spectrophotometrically by the ascorbic acid blue color method (Murphy \& Riley, 1962). Available calcium (Ca), magnesium (Mg) and potassium (K) content were measured using an Aligent 240 Atomic Absorption Spectrophotometer (AAS) after acid digestion. To determine soil heavy metals content, soil samples were digested in a 1:1 mixture of concentrated nitric and perchloric acids and were collected in $5 \mathrm{ml}$ of 2.0 M HCL as in Ure (1990). The filtered extracts were analyzed for heavy metals using AAS.

The plant samples were placed under a running tap to wash off soil particles and were oven-dried at $80^{\circ} \mathrm{C}$ for 48 hours. Each sample of the dried plant materials was ground to a fine powder using a laboratory stainless steel grinder to pass through a $1 \mathrm{~mm}$ aperture screen. Plant samples were digested in concentrated $\mathrm{H}_{2} \mathrm{SO}_{4}+\mathrm{H}_{2} \mathrm{O}_{2}+$ $\mathrm{LiSO}_{4}$ digestion mixture (Allen, Grimshaw, Parkinson, Quamby, \& Roberts, 1986) and analyzed for nutrient contents. $\mathrm{N}$ content in the extract was determined by the Micro Kjeldahl method, S content by the turbidimetric method using a spectrophotometer at $420 \mathrm{~nm}$ wavelength, $\mathrm{P}$ by vanadomolybdate yellow color in spectrophotometer and $\mathrm{Na}, \mathrm{K}, \mathrm{Ca}$ and $\mathrm{Mg}$ in an AAS. Metals of the samples were extracted by wet digestion with di acid mixture $\left(\mathrm{HNO}_{3}: \mathrm{HClO}_{4}=3: 1\right)$ and analyzed by AAS. All of the results were reported in percentage (\%) as dry weight (DW) of crops.

\subsection{Ecological Risk Assessment for Soil Pollution}

Pollution levels of $\mathrm{Cd}$ and $\mathrm{Pb}$ in the soil samples were evaluated using heavy metal indices: contamination factor $\left(C_{f}^{i}\right)$, degree of contaminations $\left(C_{d}\right)$, comprehensive potential ecological risk index $(P E R)$ and geo-accumulation index $\left(I_{\text {geo }}\right)$ (Adimalla \& Li, 2019). The equations are as follows,

$$
C_{f}^{i}=\frac{C^{i}}{C_{n}^{i}} ; C_{d}=\sum_{i=1}^{n} C_{f}^{i} ; E_{r}^{i}=T_{r}^{i} \times C_{f}^{i} ; \text { PER }=\sum_{i=1}^{m} E_{r}^{i}
$$

where, $P E R=$ comprehensive potential ecological risk index, $C_{f}^{i}=$ single heavy metal contamination factor, $C^{i}=$ content of the heavy metal in samples, $C_{n}{ }^{i}=$ background value of the heavy metal, $C_{d}=$ degree of contaminations, $E_{r}^{i}=$ potential ecological risk index, $T_{r}^{i}=$ biological toxic factor, the biological factors for cadmium $=30$ and lead $=5$ (Guo, X. Liu, Z. Liu, \& Li, 2010; Islam \& Hoque, 2014).

$$
I_{\text {geo }}=C_{n} /\left(1.5 \times B_{n}\right)
$$

where, $I_{g e o}=$ geo-accumulation index (Muller, 1969), $C_{n}=$ measured concentration of metal $\mathrm{n}$ in the soil, $B_{n}=$ geochemical background value of the element in the background sample. For lithogenic effects, 1.5 is used as a factor to minimize the variations in the background values ( $\mathrm{Yu}, \mathrm{Zhu}, \& \mathrm{Li}, 2012)$. The interpretation of geo-accumulation index $\left(I_{\text {geo }}\right)$ values are shown in Table 2.

\subsection{Statistical Analysis}

All the results are expressed on an oven-dry weight basis which was measured with three replications. Microsoft Excel 2016 program was used to compute correlations and standard deviation between the selected parameters. One-way analysis of variance (ANOVA) was performed to get the effects of $\mathrm{Cd}$ and $\mathrm{Pb}$ and the significant difference of the parameters was being tested by the least significant difference multiple range test at $\mathrm{P}<0.05$. Pared-samples T-test measured for soil samples firstly by considering soil samples all together $(\mathrm{n}=63)$, secondly by considering mean values representing the sites with different agricultural management $(\mathrm{n}=21)$ and thirdly considering specific location types $(\mathrm{n}=7)$ by IBM SPSS program. The Dendrogram grouping for cluster analysis was performed by IBM SPSS and Principal Component Analysis (PCA) was performed by XLSTAT. 
Table 2. Indices and grades of potential ecological risk of heavy metal pollution (Islam, Ahmed, Habibullah-Al-Mamun, \& Hoque, 2015)

\begin{tabular}{|c|c|c|c|c|c|c|c|c|c|}
\hline \multicolumn{4}{|c|}{ Potential Ecological Risk index $(P E R)$} & \multicolumn{4}{|c|}{ Degree of Contamination $\left(C_{d}\right)$} & \multicolumn{2}{|c|}{ Geo-accumulation index $\left(I_{\text {geo }}\right)$} \\
\hline$E_{r}^{i}$ & Grade & PER & Grade & $C_{f}^{i}$ & Degree & $C_{d}$ & Degree & $I_{\text {geo }}$ & Degree \\
\hline$E_{r}^{i}<40$ & Low & $\mathrm{RI}<65$ & Low & $C_{f}^{i}<1$ & Low & $C_{d}<5$ & Low & $I_{\mathrm{geo}}<0$ & $\begin{array}{l}\text { Practically } \\
\text { uncontaminated }\end{array}$ \\
\hline $40 \leq E_{r}^{i}<80$ & Moderate & $65 \leq \mathrm{RI}<130$ & Moderate & $1 \leq C_{f}^{i}<3$ & Moderate & $5 \leq C_{d}<10$ & Moderate & $0<I_{\mathrm{geo}}<1$ & $\begin{array}{l}\text { Uncontaminated to } \\
\text { moderately contaminated }\end{array}$ \\
\hline $80 \leq E_{r}^{i}<160$ & Considerable & $130 \leq \mathrm{RI}<260$ & Considerable & $3 \leq C_{f}^{i}<6$ & Considerable & $10 \leq C_{d}<20$ & Considerable & $1<I_{\text {geo }}<2$ & Moderately contaminated \\
\hline $160 \leq E_{r}^{i}<320$ & High & $\mathrm{RI} \leq 260$ & Very high & $C_{f}^{i} \leq 6$ & High & $C_{d} \leq 20$ & High & $2<I_{\mathrm{geo}}<3$ & $\begin{array}{l}\text { Moderately to heavily } \\
\text { contaminated }\end{array}$ \\
\hline$E_{r}^{i} \leq 320$ & Very high & & & & & & & $\begin{array}{l}3<I_{\mathrm{geo}}<4 \\
4<I_{\mathrm{geo}}<5\end{array}$ & $\begin{array}{l}\text { Heavily contaminated } \\
\text { Heavily to extremely } \\
\text { contaminated }\end{array}$ \\
\hline & & & & & & & & $I_{\mathrm{geo}}>5$ & Extremely contaminated \\
\hline
\end{tabular}

\section{Results and Discussion}

A detailed study on soil and plant properties from the vicinity of a cluster of brick kiln in the Charia area, Hathazari, Chattogram district was done to infer the impact of these brick kiln emissions.

\subsection{Physical Properties of Agricultural Soils Adjacent to the Brick Kiln Cluster}

The soil texture of the sampling areas of agricultural soil was sandy clay loam (Table 1). This textural class of soil is favorable for agricultural practice in Bangladesh. There was no significant difference between reference and agricultural soils for clay content however the samples of the location $\mathrm{C}$ had the highest average clay content $(31.43 \%)$. Water holding capacity and bulk density of soil influence the growth of crops, their rotting pattern and their ability to supply water to crops (Bisht \& Neupane 2015). Soil bulk density and water holding capacity varied from 1.37 to $1.49 \mathrm{~g} \mathrm{~cm}^{-3}$ and 31.98 to $53.10 \%$ respectively among the sampling sites. Water holding capacity positively correlated $(r=0.51, p<0.001, n=63)$, with soil clay contents but BD correlated negatively with the clay contents $(r=-0.48, p<0.001, n=63)$ of soil (Table 3$)$.

Table 3. Correlation coefficients among soil properties $(n=63)$

\begin{tabular}{|c|c|c|c|c|c|c|c|c|c|c|c|c|}
\hline Soil properties & Clay & $\mathrm{BD}$ & WHC & $\mathrm{pH}$ & Soil OM & Soil N & Soil P & Soil Na & Soil K & Soil Ca & Soil Mg & Soil $\mathrm{Pb}$ \\
\hline $\mathrm{BD}$ & $-0.48^{* * *}$ & & & & & & & & & & & \\
\hline WHC & $0.51^{* * *}$ & $-0.59^{* * *}$ & & & & & & & & & & \\
\hline $\mathrm{pH}$ & $0.30^{* *}$ & $-0.28^{*}$ & $0.52^{* * *}$ & & & & & & & & & \\
\hline Soil OM & $0.51^{* * *}$ & $-0.55^{* * *}$ & $0.63^{* * *}$ & $0.67^{* * *}$ & & & & & & & & \\
\hline Soil N & $0.43^{* * *}$ & $-0.54^{* * *}$ & $0.64^{* * *}$ & $0.67^{* * *}$ & $0.79^{* * *}$ & & & & & & & \\
\hline Soil P & 0.23 & $-0.42^{* * *}$ & $0.41^{* * *}$ & $0.73^{* * *}$ & $0.51^{* * *}$ & $0.59^{* * *}$ & & & & & & \\
\hline Soil $\mathrm{Na}$ & $0.29^{*}$ & $-0.42^{* * *}$ & $0.43^{* * *}$ & $0.49^{* * *}$ & $0.40^{* * *}$ & $0.64^{* * *}$ & $0.57^{* * *}$ & & & & & \\
\hline Soil K & $0.38^{* * *}$ & $-0.46^{* * *}$ & $0.44^{* * *}$ & $0.58^{* * *}$ & $0.59^{* * *}$ & $0.64^{* * *}$ & $0.76^{* * *}$ & $0.75^{* * *}$ & & & & \\
\hline Soil Ca & $0.33^{* *}$ & $-0.47^{* * *}$ & $0.47^{* * *}$ & $0.66^{* * *}$ & $0.49^{* * *}$ & $0.57^{* * *}$ & $0.74^{* * *}$ & $0.61^{* * *}$ & $0.68^{* * *}$ & & & \\
\hline Soil Mg & -0.18 & -0.13 & 0.16 & $0.49^{* * *}$ & $0.42^{* * *}$ & $0.46^{* * *}$ & $0.44^{* * *}$ & $0.44^{* * *}$ & $0.42^{* * *}$ & $0.45^{* * *}$ & & \\
\hline Soil $\mathrm{Pb}$ & $-0.32^{* *}$ & $0.50^{* * *}$ & $-0.44^{* * *}$ & $-0.56^{* * *}$ & $-0.48^{* * *}$ & $-0.63^{* * *}$ & $-0.49^{* * *}$ & $-0.69^{* * *}$ & $-0.62^{* * *}$ & $-0.50^{* * *}$ & $-0.56^{* * *}$ & \\
\hline Soil Cd & $-0.33^{* *}$ & $0.42^{* * *}$ & $-0.41^{* * *}$ & $-0.65^{* * *}$ & $-0.62^{* * *}$ & $-0.74^{* * *}$ & $-0.52^{* * *}$ & $-0.58^{* * *}$ & $-0.61^{* * *}$ & $-0.45^{* * *}$ & $-0.59^{* * *}$ & $0.89^{* * *}$ \\
\hline
\end{tabular}

Note. $* * *$ Correlation is significant at the 0.001 level; ** Correlation is significant at the 0.01 level; * Correlation is significant at the 0.05 level.

\subsection{Chemical Properties of Agricultural Soils Adjacent to the Brick Kiln Cluster}

The chemical properties of agricultural soils adjacent to the brick kiln cluster are presented in Table 4. The pH provides a good manifestation of soil chemical nature as it influences the availability of nutrients from the soil to plant and low $\mathrm{pH}$ in the soil increases the mobility of heavy metals, e.g., $\mathrm{Pb}, \mathrm{Cd}, \mathrm{Cr}, \mathrm{Cu}, \mathrm{Hg}, \mathrm{Ni}$, and $\mathrm{Zn}$ (Bisht \& Neupane, 2015). The $\mathrm{pH}$ values of the soil samples were in the range of 4.11 to 6.32 , which were very strongly acid to slightly acid (Hazelton \& Murphy, 2016). Reference soils (average pH 5.84) were moderately acidic in nature. The average $\mathrm{pH}$ of the studied agricultural soils was significantly different from the average $\mathrm{pH}$ of the reference soils (Table 4). When soil $\mathrm{pH}$ was compared between the sampling locations, reference site $\mathrm{R}$ was also 
found to be significantly higher than the locations A, B, D, E and F. SRDI (Soil Resource Development Institute) (2008) reported that the $\mathrm{pH}$ values of the soil series (Lama, Rangamati, Matiranga) of the Hathazari area are strongly acidic in nature. A decrease in soil $\mathrm{pH}$ due to heavy metal contamination from a brick kiln and consequent decrease in available plant nutrients and increased leaching losses of nutrients were also reported by Dey and Dey (2017).

Table 4. Chemical properties (mean $\pm \mathrm{SD}$ ) of agricultural soils adjacent to the brick kiln cluster

\begin{tabular}{|c|c|c|c|c|c|c|c|c|c|}
\hline Sites & $\mathrm{pH}$ & $\mathrm{OC}$ & $\mathrm{OM}$ & $\mathrm{TN}$ & AvP & $\mathrm{Na}$ & $\mathrm{K}$ & $\mathrm{Ca}$ & $\mathrm{Mg}$ \\
\hline & & 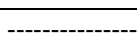 & ---- \% -----. & ------------- & $\mathrm{mg} \mathrm{kg}^{-1}$ & 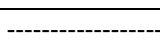 & mmol & $100 g^{-1}$ & --.-- \\
\hline CP1 & $4.87 \pm 0.08^{\mathrm{f}}$ & $0.39 \pm 0.01^{\mathrm{ab}}$ & $0.67 \pm 0.02^{\mathrm{ab}}$ & $0.16 \pm 0.00^{\mathrm{g}}$ & $7.14 \pm 0.10^{\mathrm{g}}$ & $0.67 \pm 0.02^{\mathrm{b}}$ & $0.16 \pm 0.01^{\mathrm{a}}$ & $0.63 \pm 0.04^{\mathrm{a}}$ & $0.34 \pm 0.01^{\mathrm{b}}$ \\
\hline $\mathrm{CP} 2$ & $5.39 \pm 0.03^{\mathrm{i}}$ & $0.69 \pm 0.03^{\mathrm{i}}$ & $1.19 \pm 0.05^{\mathrm{i}}$ & $0.19 \pm 0.01^{\mathrm{ij}}$ & $8.92 \pm 0.79^{\mathrm{i}}$ & $0.84 \pm 0.02^{\text {bcde }}$ & $0.27 \pm 0.01^{\mathrm{bcd}}$ & $3.07 \pm 0.01^{\mathrm{hi}}$ & $0.65 \pm 0.00^{\text {ghi }}$ \\
\hline $\mathrm{CP} 3$ & $5.26 \pm 0.03^{\mathrm{h}}$ & $0.51 \pm 0.02^{\mathrm{d}}$ & $0.88 \pm 0.03^{\mathrm{d}}$ & $0.12 \pm 0.01$ de & $6.87 \pm 0.11^{\mathrm{fg}}$ & $0.99 \pm 0.27^{\text {cdef }}$ & $0.22 \pm 0.01^{\mathrm{abc}}$ & $2.36 \pm 0.39^{\mathrm{g}}$ & $0.53 \pm 0.00^{\mathrm{d}}$ \\
\hline CP4 & $4.15 \pm 0.05^{\mathrm{a}}$ & $0.65 \pm 0.03^{\mathrm{gh}}$ & $1.11 \pm 0.05^{\mathrm{gh}}$ & $0.15 \pm 0.00^{\mathrm{f}}$ & $3.64 \pm 0.34^{\mathrm{b}}$ & $1.05 \pm 0.46^{\mathrm{ef}}$ & $0.62 \pm 0.01^{\mathrm{f}}$ & $0.92 \pm 0.01^{\text {bcde }}$ & $0.60 \pm 0.03^{\mathrm{ef}}$ \\
\hline CP5 & $5.62 \pm 0.00^{\mathrm{k}}$ & $0.84 \pm 0.00^{\mathrm{k}}$ & $1.44 \pm 0.00^{\mathrm{k}}$ & $0.19 \pm 0.00^{\mathrm{i}}$ & $12.18 \pm 0.21^{\mathrm{k}}$ & $0.77 \pm 0.06^{\text {bcde }}$ & $0.87 \pm 0.01^{\mathrm{h}}$ & $1.01 \pm 0.01^{\mathrm{cde}}$ & $0.62 \pm 0.01^{\mathrm{fg}}$ \\
\hline CP6 & $5.07 \pm 0.02^{\mathrm{g}}$ & $0.55 \pm 0.03^{\mathrm{de}}$ & $0.95 \pm 0.05^{\mathrm{de}}$ & $0.11 \pm 0.01^{\mathrm{ab}}$ & $9.48 \pm 0.06^{\mathrm{j}}$ & $0.73 \pm 0.14^{\mathrm{bcd}}$ & $0.75 \pm 0.09^{\mathrm{gh}}$ & $1.10 \pm 0.01^{\mathrm{e}}$ & $0.58 \pm 0.05^{\mathrm{e}}$ \\
\hline CP7 & $4.44 \pm 0.11^{\mathrm{b}}$ & $0.44 \pm 0.00^{\mathrm{c}}$ & $0.76 \pm 0.00^{\mathrm{c}}$ & $0.13 \pm 0.00^{\mathrm{e}}$ & $2.79 \pm 0.38^{\mathrm{a}}$ & $0.91 \pm 0.22^{\text {bcdef }}$ & $0.38 \pm 0.02^{\mathrm{e}}$ & $0.73 \pm 0.01^{\mathrm{ab}}$ & $0.23 \pm 0.00^{\mathrm{a}}$ \\
\hline $\mathrm{CP} 8$ & $5.76 \pm 0.08^{1}$ & $0.71 \pm 0.03^{\mathrm{i}}$ & $1.22 \pm 0.06^{\mathrm{i}}$ & $0.19 \pm 0.00^{\mathrm{i}}$ & $6.45 \pm 0.02^{\mathrm{f}}$ & $1.18 \pm 0.20^{\mathrm{f}}$ & $1.03 \pm 0.11^{\mathrm{i}}$ & $2.93 \pm 0.23^{\mathrm{h}}$ & $0.71 \pm 0.01^{\mathrm{k}}$ \\
\hline $\mathrm{CP} 9$ & $6.30 \pm 0.02^{\circ}$ & $0.97 \pm .04^{1}$ & $1.67 \pm 0.07^{1}$ & $0.20 \pm 0.00^{\mathrm{j}}$ & $13.44 \pm 0.07^{1}$ & $1.06 \pm 0.03^{\mathrm{ef}}$ & $1.23 \pm 0.09^{j}$ & $3.44 \pm 0.20^{\mathrm{j}}$ & $0.64 \pm 0.02^{\mathrm{fgh}}$ \\
\hline $\mathrm{CP} 10$ & $4.56 \pm 0.03^{\mathrm{cd}}$ & $0.53 \pm 0.04^{\mathrm{d}}$ & $0.91 \pm 0.07^{\mathrm{d}}$ & $0.11 \pm 0.01^{\mathrm{bc}}$ & $2.65 \pm 0.38^{\mathrm{a}}$ & $0.76 \pm 0.02^{\text {bcde }}$ & $0.36 \pm 0.01^{\mathrm{de}}$ & $1.04 \pm 0.02^{\text {cde }}$ & $0.37 \pm 0.01^{\mathrm{c}}$ \\
\hline CP11 & $5.07 \pm 0.09^{\mathrm{g}}$ & $0.62 \pm 0.00^{\mathrm{fg}}$ & $1.06 \pm 0.00^{\mathrm{fg}}$ & $0.16 \pm 0.01^{\mathrm{gh}}$ & $4.38 \pm 0.16^{\mathrm{cd}}$ & $0.89 \pm 0.03^{\text {bcdef }}$ & $0.92 \pm 0.01^{\mathrm{h}}$ & $0.84 \pm 0.02^{\mathrm{abcd}}$ & $0.62 \pm 0.01^{\mathrm{fgh}}$ \\
\hline $\mathrm{CP} 12$ & $5.37 \pm 0.02^{\mathrm{i}}$ & $0.79 \pm 0.05^{\mathrm{j}}$ & $1.36 \pm 0.08^{\mathrm{j}}$ & $0.23 \pm 0.01^{1}$ & $5.43 \pm 0.08^{\mathrm{e}}$ & $0.89 \pm 0.05^{\text {bcdef }}$ & $0.25 \pm 0.11^{\mathrm{abc}}$ & $0.95 \pm 0.05^{\text {bcde }}$ & $0.67 \pm 0.02^{\mathrm{hij}}$ \\
\hline CP13 & $4.77 \pm 0.06^{\mathrm{e}}$ & $0.59 \pm 0.03^{\text {ef }}$ & $1.01 \pm 0.05^{\mathrm{ef}}$ & $0.15 \pm 0.00^{\mathrm{f}}$ & $5.70 \pm 0.10^{\mathrm{e}}$ & $0.91 \pm 0.11^{\text {bcdef }}$ & $0.32 \pm 0.04^{\text {cde }}$ & $0.80 \pm 0.13^{\mathrm{abc}}$ & $0.71 \pm 0.02^{\mathrm{k}}$ \\
\hline CP14 & $4.55 \pm 0.04^{\mathrm{cd}}$ & $0.38 \pm 0.03^{\mathrm{ab}}$ & $0.65 \pm 0.05^{\mathrm{ab}}$ & $0.11 \pm 0.01^{\mathrm{bc}}$ & $3.83 \pm 0.26^{\mathrm{b}}$ & $0.71 \pm 0.02^{\mathrm{bc}}$ & $0.18 \pm 0.04^{\mathrm{ab}}$ & $1.01 \pm 0.00^{\mathrm{cde}}$ & $0.69 \pm 0.01^{\mathrm{ijk}}$ \\
\hline CP15 & $5.50 \pm 0.01^{\mathrm{j}}$ & $0.71 \pm 0.00^{\mathrm{i}}$ & $1.22 \pm 0.00^{\mathrm{i}}$ & $0.17 \pm 0.00^{\mathrm{h}}$ & $3.89 \pm 0.28^{\mathrm{bc}}$ & $1.03 \pm 0.14^{\mathrm{def}}$ & $0.20 \pm 0.04^{\mathrm{ab}}$ & $0.87 \pm 0.12^{\text {abcde }}$ & $0.76 \pm 0.06^{1}$ \\
\hline CP16 & $4.58 \pm 0.10^{\mathrm{d}}$ & $0.35 \pm 0.00^{\mathrm{a}}$ & $0.60 \pm 0.00^{\mathrm{a}}$ & $0.11 \pm 0.00^{\mathrm{abc}}$ & $4.56 \pm 0.13^{\mathrm{d}}$ & $0.89 \pm 0.06^{\text {bcdef }}$ & $0.19 \pm 0.06^{\mathrm{ab}}$ & $0.96 \pm 0.02^{\text {bcde }}$ & $0.63 \pm 0.00^{\mathrm{fgh}}$ \\
\hline CP17 & $5.89 \pm 0.04^{\mathrm{m}}$ & $0.44 \pm 0.00^{\mathrm{c}}$ & $0.76 \pm 0.00^{\mathrm{c}}$ & $0.12 \pm 0.01^{\mathrm{cd}}$ & $8.05 \pm 0.51^{\mathrm{h}}$ & $0.76 \pm 0.14^{\text {bcde }}$ & $0.22 \pm 0.07^{\mathrm{abc}}$ & $1.07 \pm 0.03^{\mathrm{de}}$ & $0.64 \pm 0.00^{\mathrm{fgh}}$ \\
\hline CP18 & $4.48 \pm 0.02^{\mathrm{bc}}$ & $0.40 \pm 0.00^{\mathrm{b}}$ & $0.68 \pm 0.00^{\mathrm{b}}$ & $0.10 \pm 0.01^{\mathrm{a}}$ & $7.92 \pm 0.36^{\mathrm{h}}$ & $0.41 \pm 0.03^{\mathrm{a}}$ & $0.25 \pm 0.06^{\mathrm{abc}}$ & $1.75 \pm 0.29^{\mathrm{f}}$ & $0.63 \pm 0.00^{\mathrm{fgh}}$ \\
\hline CP19 & $5.56 \pm 0.02^{\mathrm{jk}}$ & $0.67 \pm 0.00^{\mathrm{hi}}$ & $1.16 \pm 0.00^{\mathrm{hi}}$ & $0.21 \pm 0.00^{\mathrm{k}}$ & $14.35 \pm 0.49^{\mathrm{m}}$ & $1.90 \pm 0.00^{\mathrm{h}}$ & $1.54 \pm 0.04^{\mathrm{k}}$ & $3.09 \pm 0.00^{\mathrm{hi}}$ & $0.79 \pm 0.01^{\mathrm{Im}}$ \\
\hline CP20 & $6.07 \pm 0.02^{\mathrm{n}}$ & $0.71 \pm 0.03^{\mathrm{i}}$ & $1.22 \pm 0.06^{\mathrm{i}}$ & $0.22 \pm 0.00^{1}$ & $15.12 \pm 0.04^{\mathrm{n}}$ & $1.93 \pm 0.01^{\mathrm{h}}$ & $1.46 \pm 0.03^{\mathrm{k}}$ & $3.20 \pm 0.00^{\mathrm{i}}$ & $0.70 \pm 0.05^{\mathrm{jk}}$ \\
\hline $\mathrm{CP} 21$ & $5.88 \pm 0.01^{\mathrm{m}}$ & $0.71 \pm 0.03^{\mathrm{i}}$ & $1.22 \pm 0.06^{\mathrm{i}}$ & $0.22 \pm 0.01^{1}$ & $14.48 \pm 0.07^{\mathrm{m}}$ & $1.60 \pm 0.21^{\mathrm{g}}$ & $1.54 \pm 0.02^{\mathrm{k}}$ & $3.30 \pm 0.00^{\mathrm{ij}}$ & $0.81 \pm 0.00^{\mathrm{m}}$ \\
\hline \multicolumn{10}{|c|}{ Average data of study sites and reference sites } \\
\hline $\begin{array}{l}\text { Soils of crop field } \\
\text { near brick kiln cluster }\end{array}$ & $5.09^{\mathrm{x}}$ & $0.59^{\mathrm{x}}$ & $1.01^{\mathrm{x}}$ & $0.15^{\mathrm{x}}$ & $6.52^{\mathrm{x}}$ & $0.86^{\mathrm{x}}$ & $0.47^{\mathrm{x}}$ & $1.42^{\mathrm{x}}$ & $0.59^{\mathrm{x}}$ \\
\hline Reference soil & $5.84^{\mathrm{y}}$ & $0.70^{\mathrm{x}}$ & $1.20^{\mathrm{x}}$ & $0.22^{\mathrm{y}}$ & $14.65^{y}$ & $1.81^{\mathrm{y}}$ & $1.51^{\mathrm{y}}$ & $3.20^{\mathrm{y}}$ & $0.77^{\mathrm{y}}$ \\
\hline
\end{tabular}

Note. Values in the same column followed by the same letter(s) are not significantly different at $p<0.05$ according to ANOVA.

$\mathrm{OC}=$ organic carbon; $\mathrm{OM}=$ organic matter; $\mathrm{TN}=$ total nitrogen; $\mathrm{AvP}=$ available phosphorus; $\mathrm{Na}=$ sodium; $\mathrm{K}=$ potassium; $\mathrm{Ca}=$ calcium; $\mathrm{Mg}=$ magnesium

The organic carbon content of soil indicates the fertility status of soil as it directly governs soil structure development, soil air and water circulation, water holding capacity, and plant nutrients availability. The organic carbon content of healthy soil is more than $0.75 \%$ (Bisht \& Neupane 2015). The organic carbon content of the agriculture soils near the brick kiln cluster varied from $0.35 \%$ to $1.01 \%$. SRDI (2008) reported that the OC values of agricultural soils in Hathazari ranged from 1.29 to $1.59 \%$. The study found that the OC content of the agricultural land in Hathazari around the brickfield area was lower than the recorded data. The overall low value of organic matter (OM) may be due to cultivation induced organic matter decomposition and high cropping intensity of the area (Sikder, Molla, Hossain, \& Parveen, 2015). Moreover, some variation of OM may be due to the formation of chelate of OM with heavy metals produced from the brick kiln operation which makes the soil organic carbon unavailable (Sikder et al., 2015). Deposition of unburnt hydrocarbon in the form of soot on soil from aerial deposits from brick kilns and vehicles running in Chattogram-Bandarban highway can contribute to increasing $\mathrm{C}$ content in some sites.

The mean TN content of the soil samples showed that the nitrogen content in the soil varied between 0.10 to $0.24 \%$. The soils are, therefore, medium in TN content as the amount of OM in Bangladesh soil (SRDI, 2008). Decreased level of nitrogen and indefinite pattern of nitrogen accumulation due to brick kiln operation, compared to reference soil was also reported by Vista and Gautam (2018) and Sikder et al. (2015). 
The AvP content varied among the agricultural sites (2.21 to $\left.13.48 \mathrm{mg} \mathrm{kg}^{-1}\right)$. The standard level of AvP for plant cultivation is $15.76-21.0 \mathrm{mg} \mathrm{kg}^{-1}$ for acid soils (BARC [Bangladesh Agricultural Research Council], 2012). All the sampling sites including the soils of the reference area showed deficiency in AvP content. The AvP concentration was below the standard level due to the inherited low $\mathrm{pH}$ of the agricultural sites as low $\mathrm{pH}$ reduce $\mathrm{P}$ availability (Akter, Uddin, Hossain, \& Parveen, 2016). The soil AvP concentration and soil $\mathrm{pH}$ were also positively correlated $(r=0.73, p<0.001)$ (Table 3$)$ to each other. The available $\mathrm{Na}, \mathrm{K}, \mathrm{Ca}$ and $\mathrm{Mg}$ content was not found to vary widely among the sampling sites (Table 4 ). The study revealed that $40 \%$ of the collected soils

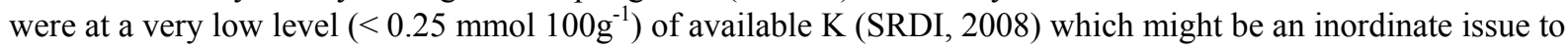
attain the highest crop yield. The average $\mathrm{Na}, \mathrm{K}$ and $\mathrm{Ca}$ concentration was highest in location $\mathrm{R}$ followed by location $\mathrm{C}$. The standard level of $\mathrm{Ca}$ and $\mathrm{Mg}$ for plant cultivation is $2.26-3.00 \mathrm{mmol} 100 \mathrm{~g}^{-1}$ and $0.56-0.75 \mathrm{mmol}$ $100 \mathrm{~g}^{-1}$ respectively for acid soils (BARC, 2012). Soil Ca and $\mathrm{Mg}$ content in some sites were high due to high rainfall, which could leach $\mathrm{Ca}$ and $\mathrm{Mg}$ from surrounding hills to the acid soils, moreover Ca could impetuously be added to the soil as a part of P- and S-fertilizers (Moslehuddin, Laizoo, \& Egashira, 1997).

Soil $\mathrm{pH}$ was highest in site CP9 in combination with the highest OM, TN and AvP. Soil factors-TN $(r=0.79, p<$ $0.001)$ and $\operatorname{AvP}(r=0.51, p<0.001)$ were significantly correlated to soil OM content. TN and AvP were significantly correlated to each other $(r=0.59, p<0.001)$ and a positive significant $(r=0.67, p<0.001)$ correlation of $\mathrm{OM}$ and $\mathrm{pH}$ was found for the soils (Table 3). Exchangeable $\mathrm{Na}, \mathrm{K}, \mathrm{Ca}$ and $\mathrm{Mg}$ were positively correlated $(p<0.001)$ to the OM content of soil (Table 3).

\subsection{Distribution of $\mathrm{Cd}$ and $\mathrm{Pb}$ in Agricultural Soils Adjacent to the Brick Kiln Cluster}

The concentration of $\mathrm{Cd}$ and $\mathrm{Pb}$ in analyzed soil samples was compared with guideline values for agricultural soil (dry soil $\mathrm{pH}<6.5$ ) by the National Environmental Protection Agency of China (GB 15618, 1995) (Chen, Meng, Li, Zhao, \& Wen-di, 2018). 89\% of the sampling sites were highly contaminated with Cd which exceeded the maximum permissible limit (Table 5). The $\mathrm{Pb}$ content was found within the permissible limit in the agricultural sites in the vicinity of the brick kiln cluster (Table 5). The Cd content was highest $\left(1.07 \mathrm{mg} \mathrm{kg}^{-1}\right)$ in the soils of sampling site CP6, followed by the soils of CP1 and CP3 $\left(1.00 \mathrm{mg} \mathrm{kg}^{-1}\right)$ of the agricultural soil. The highest value of $\mathrm{Pb}$ was $52.07 \mathrm{mg} \mathrm{kg}^{-1}$ recorded at agricultural site $\mathrm{CP}$. The descriptive statistics of $\mathrm{Cd}$ and $\mathrm{Pb}$ concentration showed divergence among the sites. As the fumes emerged from the brick kiln cluster dispersed on the agricultural fields through wind and deposited on the crop and soils, there was no uniform distribution of $\mathrm{Cd}$ and $\mathrm{Pb}$ in the area. Soil $\mathrm{Pb}$ concentration showed a strong significant correlation with soil $\mathrm{Cd}$ concentration $(r=$ $0.89, p<0.001)$ designating their strong associations and hence, their same source of inclusion in the soil. Cd and $\mathrm{Pb}$ concentration values were unsymmetrical with positive skewness values of 0.07 and 1.01 respectively, indicating the normality of the data set for these heavy metals. The calculated coefficient of variation (CV) was $41.23 \%$ and $29.21 \%$, indicating moderate variation, which expresses heterogeneous contingency (Zhou et al., 2016), indicating that the sources of heavy metal were not natural, the sources were anthropogenic. Dey and Dey (2017) and Ravankhah et al. (2017) reported the heavy metals, i.e., $\mathrm{Pb}, \mathrm{Cd}, \mathrm{Cr}$ and $\mathrm{Ni}$ as a major environmental impact factor near brick kilns. 
Table 5. Descriptive statistics of $\mathrm{Cd}$ and $\mathrm{Pb}\left(\mathrm{mg} \mathrm{kg}^{-1}\right)$ in agricultural soils adjacent to the brick kiln cluster and comparison with some reference values

\begin{tabular}{|c|c|c|}
\hline Descriptive statistics of contaminated soils & $\mathrm{Cd}$ & $\mathrm{Pb}$ \\
\hline Minimum, $\mathrm{mg} \mathrm{kg}^{-1}$ & 0.25 & 19.05 \\
\hline Maximum, $\mathrm{mg} \mathrm{kg}^{-1}$ & 1.08 & 52.10 \\
\hline Mean & 0.63 & 29.68 \\
\hline Geometric mean & 0.58 & 28.85 \\
\hline Median & 0.63 & 27.77 \\
\hline Standard deviation & 0.26 & 8.57 \\
\hline Kurtosis & -1.25 & 0.85 \\
\hline Skewness & 0.10 & 1.09 \\
\hline Coefficient of variation $\%$ & 41.23 & 29.21 \\
\hline$\%$ Sample which exceeded standard value & 88.89 & 0 \\
\hline Guideline values for agricultural soil ${ }^{\mathrm{a}}($ dry soil $\mathrm{pH}<6.5)$ & 0.30 & 250 \\
\hline Threshold of elements in natural background soil in China ${ }^{a}$ & 0.20 & 35 \\
\hline Safe limit of India ${ }^{\mathrm{b}}$ & $3-6$ & $250-500$ \\
\hline Uncontaminated soil & $\mathrm{Cd}$ & $\mathrm{Pb}$ \\
\hline Soil $^{\mathrm{c}}$ & 1 & 50 \\
\hline Soil $^{\mathrm{d}}$ & 0.06 & 100 \\
\hline Content in lithosphere $\left(\mathrm{mg} \mathrm{kg}^{-1}\right)^{\mathrm{e}}$ & $0.1-0.5$ & 16 \\
\hline Common range for soils $\left(\mathrm{mg} \mathrm{kg}^{-1}\right)^{\mathrm{e}}$ & $0.10-345$ & $2-200$ \\
\hline Common range for soils in Bangladesh $\left(\mathrm{mg} \mathrm{kg}^{-1}\right)^{\mathrm{f}}$ & $<1$ & 32 \\
\hline
\end{tabular}

Note. ${ }^{\mathrm{a}}$ Chen et al., 2018; ${ }^{\mathrm{b}}$ Awashthi, 2000; ${ }^{\mathrm{c}}$ Kabata-Pendias \& Pendias, 1992; ${ }^{\mathrm{d}}$ DeTemmerman et al., 1984; Lindsay, 1979; ${ }^{\mathrm{f}}$ Huq \& Alam, 2005.

The correlation matrix among the soil nutrient factors shows a highly significant positive correlation $(p<0.001)$, i.e., with soil $\mathrm{OM}$ and soil $\mathrm{N}, \mathrm{P}, \mathrm{Na}, \mathrm{K}, \mathrm{Ca}$, and $\mathrm{Mg}$ but negative correlations with the soil $\mathrm{Cd}$ and $\mathrm{Pb}$ concentrations in the agricultural sites near the brick kiln cluster (Table 3). Soil $\mathrm{pH}$ showed a significant negative correlation $(p<0.001)$ with $\mathrm{Cd}$ and $\mathrm{Pb}$, which may suggest that $\mathrm{pH}$ influenced the distributions of these metals in soils. Soil $\mathrm{pH}$ is one of the major factors in controlling the available content of heavy metals in solution as it affects directly their solubility along within the soil environment (Diatta, Grzebisz, Frackowiak-Pawlak, Andrzejewska, \& Brzykcy, 2014; Sikder et al., 2015). Heavy metal cations are most mobile in acid soils. There was a significant $(p<0.001)$ negative correlation between soil $\mathrm{Cd}$ and $\mathrm{Pb}$ concentrations and the content of soil OM, TN, AvP and other available soil nutrient elements (Table 3). Bisht and Neupane (2015) also found an inversely proportional relation between heavy metal accumulation rate and concentrations of organic carbon as an increased concentration of heavy metals decreased soil OM formation. Again, OM in the soil can decrease the mobility and bioavailability of heavy metals by complexation (metal chelate complexes) and adsorption mechanism. However, because of the low content of $\mathrm{OM}$, the availability of $\mathrm{Cd}$ and $\mathrm{Pb}$ from suspended particles to the soil solution can intensify.

\subsection{Soil Contamination Assessment}

The concentrations of $\mathrm{Cd}$ and $\mathrm{Pb}$ in agricultural soils based on the background values from the brick kiln cluster shows the scope of anthropogenic pollution. The environmental risk of the agricultural soils was in contamination level as assessed using $C_{f}^{i}, E_{r}^{i}, P E R$ and $I_{\text {geo }}$ (Table 2).

The ranges of $C_{f}^{i}$ were 1.71-7.37 for $\mathrm{Cd}$, and 2.36-6.46 for $\mathrm{Pb}$ in the agricultural soils in the vicinity of the brick kiln cluster. The order of mean $C_{f}^{i}$ was $\mathrm{Cd}(4.35)>\mathrm{Pb}$ (3.72). The result showed that $\mathrm{Cd}$ was the primary pollutant and the mean contamination level was in a considerable degree (Figure 1). In most soil samples, the $E_{r}{ }^{i}$ factors of Cd ranged above 40, and contamination levels were moderate risk to high risk. The $P E R$ which shows the extent of contamination of the sampling sites indicated moderate to considerable level of contamination in the agricultural soils around the brick kiln cluster (Figure 1). However, no potential ecological risk was found with reference sites, for which the sum of toxic units was lower than 40 . 


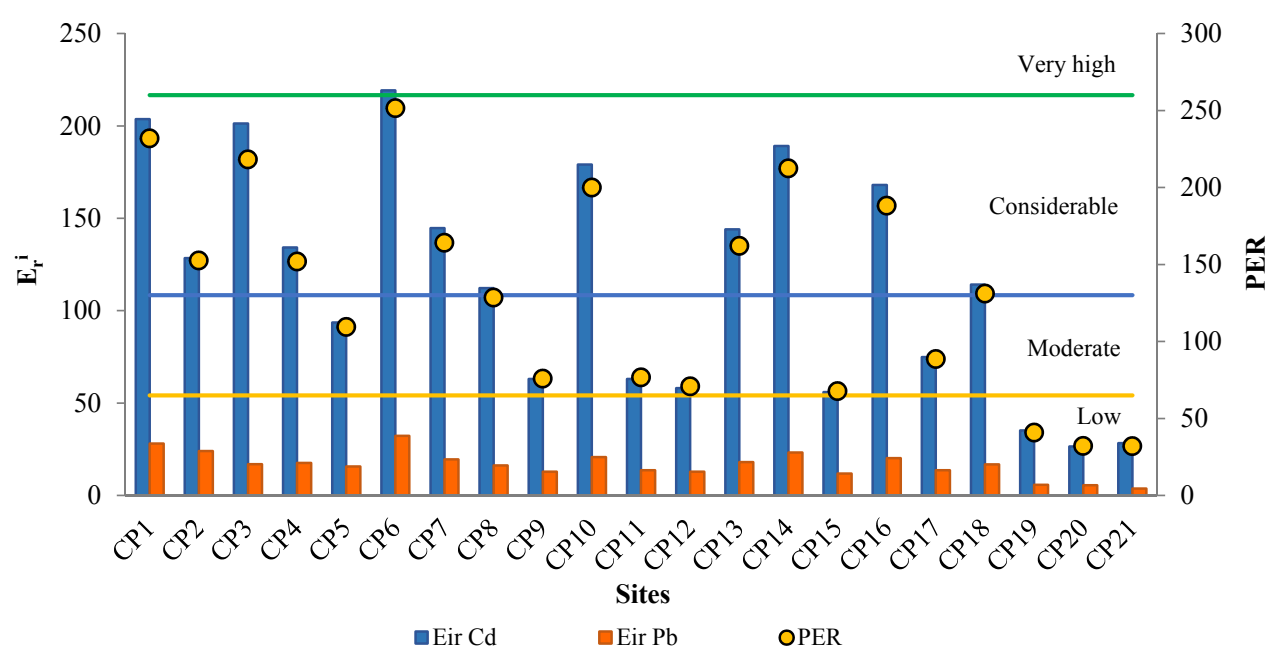

Figure 1. Potential ecological risk factor $\left(E_{r}^{i}\right)$, risk index $(P E R)$ and pollution degree of heavy metals in agricultural soils adjacent to the brick kiln cluster

The geo-accumulation Index $\left(I_{\text {geo }}\right)$ which is an effective numerical model, to evaluate the heavy metal contamination in agricultural soils was found higher than 0 for the agricultural soils near the brick kiln cluster. The value indicates the moderate contamination by of $\mathrm{Cd}$ and $\mathrm{Pb}$ in soils by anthropogenic sources (Table 2). The ranking of $I_{\text {geo }}$ value is $\mathrm{Cd}(1.40)>\mathrm{Pb}(1.25)$.

In our study area, brick kiln operation discharges a huge amount of fumes containing heavy metals into the surrounding agricultural land. The higher level of heavy metal concentrations, e.g., $\mathrm{Cd}$ and $\mathrm{Pb}$ in the vicinity of the brick kiln than in the reference site indicates that nutritional status, as well as soil quality, is deteriorating, as was also observed by Khan et al., (2007b) and Dey and Dey (2017). The result was likely related to the long term extensive use of $\mathrm{Cd}$ based fuels in brick kilns. $\mathrm{Cd}$ and $\mathrm{Pb}$ may originate from precipitation of aerosol particles released from brick kilns when tires are burned during the baking of bricks (Bisht \& Neupane, 2015). Fly ash or coal ash contains an appreciable amount of $\mathrm{Cd}$ and $\mathrm{Pb}$ (Jiang, Xin, Jun, Yang, \& Zhang, 2007). Therefore, dumping of fly ash in this zone and when they fall as dust in some places from brick kiln fumes, the concentration of these two elements becomes high with time. The distribution of fly ash produced from brick kiln operation is the most important contributor to heavy metal contamination to the surrounding agricultural soils (Sikder et al., 2015). Some sites were found to be non-contaminated although the other sites in the same location were found contaminated with deposited brick kiln fumes (CP9 at site C and CP15 at site E). Tall trees near the agricultural fields can act as a barrier for the aerial deposits of brick kiln fumes to the agricultural soils growing near the brick kiln cluster by reducing the heavy metal concentrations. Therefore, planting trees can be considered as an effective protective measure for existing crop fields that were close to a brick kiln cluster.

\subsection{Nutrient Element Concentration in Selected Crop Plants}

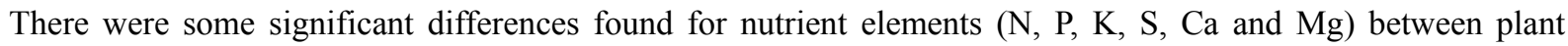
species among the different sampling sites (Table 6). Plant uptake of the elements followed the same trends as in soils of the sampling sites (Tables 4 and 6). Macronutrient accumulation was not prominent in the crop plants of the study sites. 
Table 6. Nutrient element concentration in selected plant species of agricultural soil adjacent to the brick kiln cluster

\begin{tabular}{|c|c|c|c|c|c|c|c|}
\hline Sampling site & Crop plants & $\mathrm{N}$ & $\mathrm{P}$ & $\mathrm{K}$ & $\mathrm{S}$ & $\mathrm{Ca}$ & $\mathrm{Mg}$ \\
\hline & & \multicolumn{6}{|c|}{ } \\
\hline CP1 & Solanum tuberosum & $2.23 \pm 0.02^{\mathrm{ab}}$ & $0.23 \pm 0.02^{\mathrm{d}}$ & $1.29 \pm 0.97^{\mathrm{ab}}$ & $0.25 \pm 0.02^{\mathrm{ab}}$ & $0.29 \pm 0.02^{\mathrm{ab}}$ & $0.28 \pm 0.01^{\mathrm{a}}$ \\
\hline $\mathrm{CP} 2$ & Artemisia vulgaris & $2.91 \pm 2.21^{\mathrm{abc}}$ & $0.25 \pm 0.03^{\mathrm{d}}$ & $1.92 \pm 1.94^{\text {abcde }}$ & $0.65 \pm 0.04^{\text {bcdef }}$ & $0.69 \pm 0.00^{\text {cdef }}$ & $0.71 \pm 0.24^{\text {def }}$ \\
\hline $\mathrm{CP} 3$ & Ipomoea batatas & $2.22 \pm 0.52^{\mathrm{ab}}$ & $0.18 \pm 0.05^{\mathrm{bc}}$ & $6.33 \pm 0.76^{\mathrm{f}}$ & $0.17 \pm 0.03^{\mathrm{a}}$ & $0.54 \pm 0.01^{\text {abcde }}$ & $0.53 \pm 0.01^{\mathrm{cd}}$ \\
\hline $\mathrm{CP} 4$ & Capsicum species & $2.24 \pm 0.30^{\mathrm{ab}}$ & $0.08 \pm 0.01^{\mathrm{a}}$ & $4.81 \pm 2.60^{\text {abcdef }}$ & $0.27 \pm 0.01^{\mathrm{abc}}$ & $0.77 \pm 0.19^{\text {ef }}$ & $0.74 \pm 0.09^{\text {ef }}$ \\
\hline CP5 & Oryza sativa & $2.92 \pm 1.54^{\mathrm{abc}}$ & $0.41 \pm 0.01^{\mathrm{h}}$ & $5.66 \pm 3.91^{\mathrm{def}}$ & $0.34 \pm 0.22^{\text {abcde }}$ & $1.21 \pm 0.01^{\mathrm{h}}$ & $0.85 \pm 0.04^{\mathrm{f}}$ \\
\hline CP6 & Solanum tuberosum & $2.21 \pm 0.01^{\mathrm{ab}}$ & $0.32 \pm 0.00^{\mathrm{e}}$ & $1.67 \pm 0.16^{\mathrm{abcd}}$ & $0.15 \pm 0.00^{\mathrm{a}}$ & $0.41 \pm 0.13^{\mathrm{abc}}$ & $0.31 \pm 0.07^{\mathrm{ab}}$ \\
\hline CP7 & Oryza sativa & $3.83 \pm 0.99^{\mathrm{bcd}}$ & $0.25 \pm 0.01^{\mathrm{d}}$ & $4.13 \pm 3.50^{\mathrm{abcdef}}$ & $0.14 \pm 0.01^{\mathrm{a}}$ & $0.37 \pm 0.15^{\mathrm{ab}}$ & $0.80 \pm 0.14^{\mathrm{f}}$ \\
\hline CP8 & Trichosanthes anguina & $6.41 \pm 2.31^{\mathrm{efg}}$ & $0.39 \pm 0.00^{\mathrm{gh}}$ & $2.80 \pm 1.37^{\text {abcdef }}$ & $0.29 \pm 0.08^{\mathrm{abcd}}$ & $1.18 \pm 0.01^{\mathrm{gh}}$ & $0.91 \pm 0.01^{\mathrm{fg}}$ \\
\hline СР9 & Raphanus sativus & $7.34 \pm 1.33^{\mathrm{fg}}$ & $0.39 \pm 0.06^{\mathrm{gh}}$ & $5.96 \pm 1.70^{\mathrm{ef}}$ & $0.67 \pm 0.01^{\text {cde }}$ & $0.56 \pm 0.21^{\text {bcde }}$ & $1.06 \pm 0.01^{\mathrm{g}}$ \\
\hline CP10 & Oryza sativa & $2.47 \pm 0.03^{\mathrm{ab}}$ & $0.14 \pm 0.00^{\mathrm{b}}$ & $3.44 \pm 3.18^{\mathrm{abcdef}}$ & $0.17 \pm 0.00^{\mathrm{a}}$ & $0.74 \pm 0.07^{\text {def }}$ & $0.88 \pm 0.01^{\mathrm{fg}}$ \\
\hline CP11 & Brassica nigra & $4.49 \pm 2.02^{\mathrm{cd}}$ & $0.31 \pm 0.01^{\mathrm{e}}$ & $1.10 \pm 0.42^{\mathrm{a}}$ & $0.33 \pm 0.03^{\text {abcdef }}$ & $0.91 \pm 0.01^{\mathrm{fg}}$ & $0.53 \pm 0.07^{\mathrm{cd}}$ \\
\hline $\mathrm{CP} 12$ & Capsicum species & $3.83 \pm 0.84^{\mathrm{bcd}}$ & $0.36 \pm 0.01^{\mathrm{fg}}$ & $1.52 \pm 0.01^{\mathrm{abcd}}$ & $0.45 \pm 0.01^{\mathrm{abcdef}}$ & $0.96 \pm 0.01^{\mathrm{fgh}}$ & $0.75 \pm 0.02^{\mathrm{ef}}$ \\
\hline CP13 & Capsicum species & $2.31 \pm 0.64^{\mathrm{ab}}$ & $0.33 \pm 0.02^{\mathrm{ef}}$ & $2.25 \pm 0.05^{\text {abcde }}$ & $0.72 \pm 0.04^{\mathrm{e}}$ & $0.55 \pm 0.22^{\text {bcde }}$ & $0.81 \pm 0.01^{\mathrm{f}}$ \\
\hline CP14 & Artemisia vulgaris & $1.83 \pm 0.04^{\mathrm{a}}$ & $0.17 \pm 0.02^{\mathrm{bbc}}$ & $1.26 \pm 0.02^{\mathrm{ab}}$ & $0.29 \pm 0.01^{\mathrm{abcd}}$ & $0.48 \pm 0.06^{\mathrm{abc}}$ & $0.58 \pm 0.25^{\text {cde }}$ \\
\hline $\mathrm{CP} 15$ & Raphanus sativus & $6.75 \pm 0.03^{\mathrm{efg}}$ & $0.19 \pm 0.00^{\mathrm{c}}$ & $1.46 \pm 0.02^{\mathrm{abc}}$ & $0.43 \pm 0.02^{\text {abcdef }}$ & $0.33 \pm 0.31^{\mathrm{ab}}$ & $0.89 \pm 0.01^{\mathrm{fg}}$ \\
\hline CP16 & Artemisia vulgaris & $2.91 \pm 0.06^{\mathrm{abc}}$ & $0.18 \pm 0.01^{\mathrm{bc}}$ & $1.60 \pm 0.13^{\mathrm{abcd}}$ & $0.50 \pm 0.11^{\mathrm{abcdef}}$ & $0.34 \pm 0.11^{\mathrm{ab}}$ & $0.48 \pm 0.00^{\mathrm{bc}}$ \\
\hline CP17 & Solanum lycopersicum & $5.55 \pm 0.32^{\mathrm{def}}$ & $0.27 \pm 0.02^{\mathrm{d}}$ & $1.58 \pm 0.34^{\mathrm{abcd}}$ & $0.64 \pm 0.04^{\text {bcdef }}$ & $0.54 \pm 0.13^{\text {abcde }}$ & $0.34 \pm 0.15^{\mathrm{ab}}$ \\
\hline CP18 & Brassica nigra & $5.06 \pm 0.02^{\mathrm{de}}$ & $0.24 \pm 0.00^{\mathrm{d}}$ & $1.87 \pm 0.01^{\mathrm{abcde}}$ & $0.42 \pm 0.07^{\text {abcdef }}$ & $0.25 \pm 0.38^{\mathrm{a}}$ & $0.59 \pm 0.21^{\text {cde }}$ \\
\hline CP19 & Oryza sativa & $7.74 \pm 0.02^{\mathrm{g}}$ & $0.42 \pm 0.01^{\mathrm{h}}$ & $5.63 \pm 4.54^{\mathrm{def}}$ & $0.61 \pm 0.01^{\text {bcdef }}$ & $1.18 \pm 0.00^{\mathrm{gh}}$ & $0.89 \pm 0.01^{\mathrm{fg}}$ \\
\hline $\mathrm{CP} 20$ & Solanum tuberosum & $7.17 \pm 0.01^{\mathrm{fg}}$ & $0.48 \pm 0.02^{\mathrm{i}}$ & $5.52 \pm 0.09^{\text {cdef }}$ & $0.60 \pm 0.05^{\text {bcdef }}$ & $1.17 \pm 0.04^{\mathrm{gh}}$ & $0.86 \pm 0.03^{\mathrm{f}}$ \\
\hline $\mathrm{CP} 21$ & Vigna mungo & $7.42 \pm 0.27^{\mathrm{g}}$ & $0.46 \pm 0.02^{\mathrm{i}}$ & $5.39 \pm 4.11^{\text {bcdef }}$ & $0.69 \pm 0.91^{\mathrm{de}}$ & $1.14 \pm 0.21^{\mathrm{gh}}$ & $0.82 \pm 0.11^{\mathrm{f}}$ \\
\hline \multicolumn{8}{|c|}{ Average data of study sites and reference sites } \\
\hline \multicolumn{2}{|c|}{ Crop plants near brick kiln cluster } & $3.75^{\mathrm{x}}$ & $0.26^{\mathrm{x}}$ & $2.81^{\mathrm{x}}$ & $0.38^{\mathrm{x}}$ & $0.62^{\mathrm{x}}$ & $0.67^{\mathrm{x}}$ \\
\hline \multicolumn{2}{|c|}{ Crop plants of reference sites } & $7.44^{\mathrm{y}}$ & $0.45^{\mathrm{y}}$ & $5.51^{\mathrm{y}}$ & $0.63^{y}$ & $1.16^{\mathrm{y}}$ & $0.86^{\mathrm{x}}$ \\
\hline \multicolumn{2}{|c|}{$\begin{array}{l}\text { Typical concentrations sufficient for plant growth } \\
\text { (Epstein 1965) }\end{array}$} & 1.5 & 0.2 & 1.0 & 0.1 & 0.5 & 0.2 \\
\hline
\end{tabular}

Note. Values in the same column followed by the same letter(s) are not significantly different at $p<0.05$ according to ANOVA.

$\mathrm{N}=$ nitrogen; $\mathrm{P}=$ phosphorus $\mathrm{K}=$ potassium; $\mathrm{S}$ = sulphur; $\mathrm{Ca}=$ calcium; $\mathrm{Mg}=$ magnesium.

The nitrogen content of the plant samples in the agricultural soils varied between 1.45 to $9.04 \%$. The highest accumulation of $\mathrm{N}$ in the plant was in Raphanus sativus (site CP9) and the lowest was in Artemisia vulgaris (site CP14). Average results indicated that at reference sites, plants accumulated the highest amount of $\mathrm{N}(7.44 \%)$ compared to agricultural soils (3.75\%) in the vicinity of the brick kiln cluster. The P content of the samples was within the range of 0.07 to $0.46 \%$ in the agricultural soils near the brick kiln cluster and in the reference site, the average concentration was $0.45 \%$ (Table 6). The highest P concentration was found in Oryza sativa (site CP5) and the lowest $\mathrm{P}$ was obtained from Capsicum species (site CP4). The $\mathrm{K}$ content in crop plants ranged from 0.33 to $10.13 \%$ in the agricultural soils near the brick kiln and $5.51 \%$ in the reference soil of the study area. The highest accumulation of K in the plant was in Ipomoea batatas (site CP3) followed by Oryza sativa (site CP5) and the lowest was in Brassica nigra (site CP11). S accumulation was not high in the plants as reported by some authors in brick kiln areas (Sikder et al., 2015). The plant S concentration was recorded ranging from 0.13 to $0.75 \%$ in the agricultural soils near brick kiln and $0.63 \%$ in the reference soils. The mean value of plant $\mathrm{S}$ concentration was found $0.38 \%$ in the agricultural soils. The highest plant $\mathrm{S}$ concentration was found in Capsicum species (site CP13) and the lowest in Oryza sativa (site CP7). The concentration of plant $\mathrm{Ca}$ and $\mathrm{Mg}$ was not found to vary widely among the sampling sites (Table 6).

Application of injudicious and elevated levels of synthetic fertilizers in the agricultural fields imbalanced the content of nutrients in the agricultural soil near the brick kiln cluster. The plant nutrient accumulation is affected by fertilizer application (Yousaf et al., 2017). pH, soil OM and TN had a positive significant relation with plant nutrient concentrations (Table 7). Nutrients accumulation in the plant depends on available nutrient concentrations in soil. Almost all the sites near the brick kiln cluster showed lower content of nutrients than in reference sites. It might be due to the heavy metal in polluted soils that could hamper plant functionality for the uptake of mineral nutrients from the soil. There was an inversely proportional significant correlation $(p<0.001)$ between the heavy metal accumulation rate in soil and concentrations of nutrients in the plant (Table 7). 
Table 7. Correlation coefficients among soil and plant properties $(n=63)$

\begin{tabular}{|c|c|c|c|c|c|c|c|c|}
\hline Soil properties & Plant N & Plant P & Plant K & Plant S & Plant $\mathrm{Ca}$ & Plant Mg & Plant Pb & Plant Cd \\
\hline Clay 1 & $0.32^{* *}$ & $0.33^{* *}$ & $0.40^{* * *}$ & 0.01 & $0.34^{* *}$ & $0.68^{* * *}$ & -0.19 & -0.24 \\
\hline $\mathrm{BD}$ & -0.20 & $-0.28^{*}$ & $-0.55^{* * *}$ & -0.15 & $-0.51^{* * *}$ & $-0.43^{* * *}$ & $0.28^{*}$ & $0.34^{* *}$ \\
\hline WHC & $0.29^{*}$ & $0.39^{* * *}$ & $0.35^{* *}$ & 0.10 & $0.49^{* * *}$ & $0.45^{* * *}$ & -0.14 & $-0.43^{* * *}$ \\
\hline pH & $0.67^{* * *}$ & $0.74^{* * *}$ & $0.27^{*}$ & $0.40^{* * *}$ & $0.48^{* * *}$ & $0.31^{*}$ & -0.14 & $-0.44^{* * *}$ \\
\hline Soil OM & $0.44^{* * *}$ & $0.59^{* * *}$ & $0.35^{* *}$ & $0.26^{*}$ & $0.59^{* * *}$ & $0.65^{* * *}$ & -0.18 & $-0.46^{* * *}$ \\
\hline Soil N & $0.54^{* * *}$ & $0.72^{* * *}$ & $0.29^{* *}$ & $0.37^{* *}$ & $0.68^{* * *}$ & $0.54^{* * *}$ & -0.23 & $-0.62^{* * *}$ \\
\hline Soil P & $0.55^{* * *}$ & $0.78^{* * *}$ & $0.43^{* * *}$ & $0.42^{* * *}$ & $0.47^{* * *}$ & 0.22 & 0.00 & $-0.29^{*}$ \\
\hline Soil Na & $0.59^{* * *}$ & $0.55^{* * *}$ & $0.37^{* *}$ & $0.28^{*}$ & $0.60^{* * *}$ & $0.44^{* * *}$ & -0.18 & $-0.52^{* * *}$ \\
\hline Soil K & $0.63^{* * *}$ & $0.75^{* * *}$ & $0.45^{* * *}$ & $0.25^{*}$ & $0.70^{* * *}$ & $0.44^{* * *}$ & -0.09 & $-0.44^{* * *}$ \\
\hline Soil Ca & $0.60^{* * *}$ & $0.57^{* * *}$ & $0.41^{* * *}$ & $0.37^{* *}$ & $0.46^{* * *}$ & $0.42^{* * *}$ & -0.17 & $-0.26^{*}$ \\
\hline Soil Mg & $0.47^{* * *}$ & $0.43^{* * *}$ & 0.04 & $0.49^{* * *}$ & $0.39^{* * *}$ & $0.27^{*}$ & -0.22 & $-0.47^{* * *}$ \\
\hline Soil Pb & $-0.75^{* * *}$ & $-0.54^{* * *}$ & $-0.38^{* *}$ & $-0.43^{* * *}$ & $-0.56^{* * *}$ & $-0.54^{* * *}$ & $0.51^{* * *}$ & $0.76^{* * *}$ \\
\hline Soil Cd & $-0.78^{* * *}$ & $-0.63^{* * *}$ & -0.21 & $-0.49^{* * *}$ & $-0.55^{* * *}$ & $-0.51^{* * *}$ & $0.42^{* * *}$ & $0.80^{* * *}$ \\
\hline
\end{tabular}

Correlation is significant at the 0.05 level.

\subsection{Characterization of Sampling Sites Based on the Elemental Composition of Soils and Crop Plants}

The principal component analysis (PCA) is used to analyze data for investigating metal sources and anthropogenic activities (Kormoker et al., 2019). The depositions of atmospheric particulates released by brick kiln clusters were found to contribute to $\mathrm{Cd}$ and $\mathrm{Pb}$ in investigated agricultural soils. A PCA was performed on a correlation matrix of the data obtained on nutrient concentration in soils of the sampling site and corresponding crop plants and soil contamination index (Figure 2).

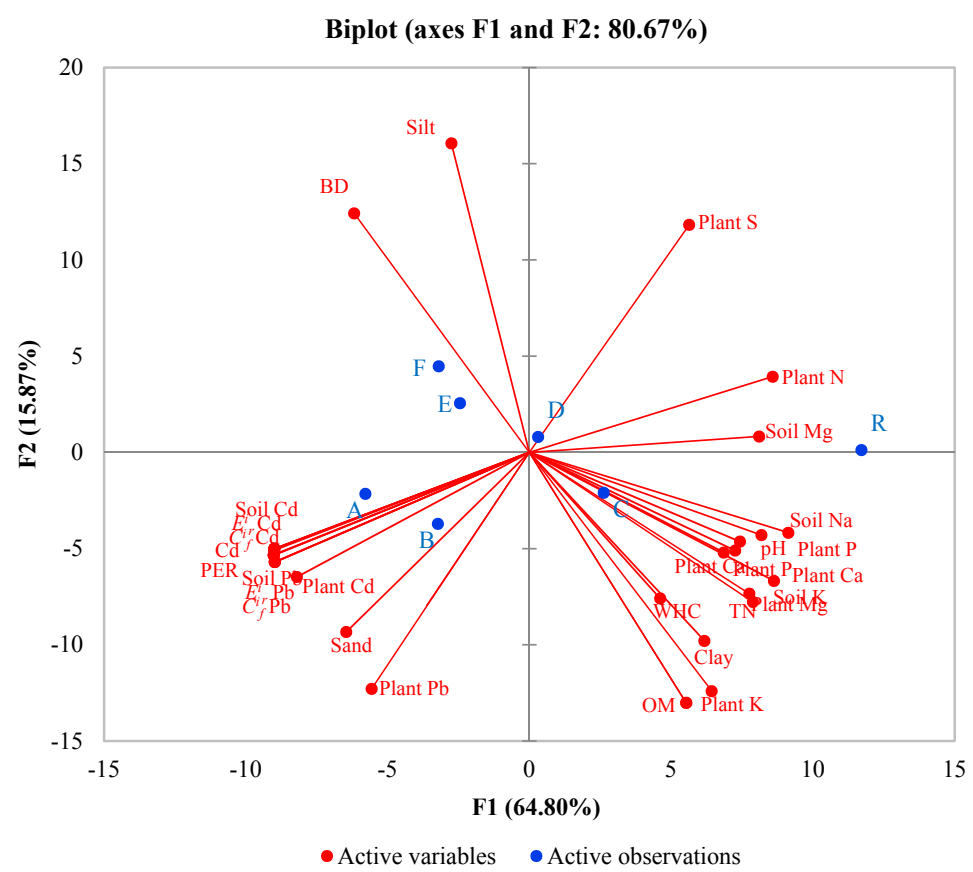

Figure 2. The principal component analysis (PCA) plot showing the similarity of agricultural soils adjacent to the brick kiln cluster considering heavy metal indices in sampling sites and nutrient concentration in soils and plant

Note. $\mathrm{BD}=$ bulk density; $\mathrm{WHC}=$ water holding capacity; $\mathrm{OM}=$ organic matter; $\mathrm{TN}=$ total nitrogen in soil; AvP $=$ available phosphorus in soil; $\mathrm{N}=$ nitrogen; $\mathrm{P}=$ phosphorus; $\mathrm{K}=$ potassium; $\mathrm{S}=$ sulphur; $\mathrm{Ca}=$ calcium; $\mathrm{Mg}=$ magnesium; $\mathrm{Na}=$ sodium; $\mathrm{K}$ = potassium; $\mathrm{Ca}=$ calcium; $\mathrm{Mg}=$ magnesium; $\mathrm{Cd}=$ cadmium; $\mathrm{Pb}=$ lead; $P E R=$ comprehensive potential ecological risk index, $C_{f}^{i} \mathrm{Cd}=$ cadmium contamination factor; $C_{f}^{i} \mathrm{~Pb}=$ lead contamination factor; $\mathrm{C}_{\mathrm{d}}=$ degree of contaminations, $E_{r}{ }^{i} \mathrm{Cd}=$ potential ecological risk index for cadmium; $E_{r}{ }^{i}$ $\mathrm{Pb}=$ potential ecological risk index for lead. 
The PCA revealed a strong relationship between nutrient content in soils and plants and they varied together in the same trend upon toxicity index of heavy metals. The PCA analysis also showed that nutrient content in soils and plant were highly associated with soil $\mathrm{pH}, \mathrm{OM}$ and $\mathrm{TN} . \mathrm{Cd}$ and $\mathrm{Pb}$ were significantly and positively associated with the heavy metal indices which indicate the anthropogenic release of heavy metals from the emissions of the brick kilns (Dey \& Dey, 2017). Hierarchical cluster analysis elucidates $45 \%$ deterioration and degradation of soil and plant quality was due to brick kiln operation near the agricultural field. The results thus indicate that loss of fertility as soil nutrient concentration reduced for brick kiln operation could hamper plant productivity.

\section{Conclusion}

This study manifested that the brick kilns emission from the rigorous unrestricted operation of brick kilns in the study area was a potential source of pollution in terms of heavy metal indices and reduced nutrient status of soil and plants in the study area. The present circumstances may eventually provoke great repercussions. The result presented in this paper can act as a database for the specification of nutrients and soil pollution of this study area which can be used for better resource management and effective monitoring. It is suggested that the Environmental Impact Assessment (EIA) should be done while establishing brick kilns in the area and nutrient and heavy metal concentration in crop plants should be regularly monitored. Planting trees could be very effective as a mitigation strategy to minimize soil degradation and environmental pollution from the brick kiln exhaust.

\section{References}

Adimalla, N., \& Li, P. (2019). Occurrence, health risks, and geochemical mechanisms of fluoride and nitrate in groundwater of the rock-dominant semi-arid region, Telangana State, India. Human and Ecological Risk Assessment: An International Journal, 25(1-2), 81-103. https://doi.org/10.1080/10807039.2018.1480353

Akter, R., Uddin, M. J., Hossain, M. F., \& Parveen, Z. (2016). Influence of brick manufacturing on phosphorus and sulfur in different agro-ecological soils of Bangladesh. Bangladesh Journal of Scientific Research, 29(2), 123-131. https://doi.org/10.3329/bjsr.v29i2.32329

Allen, S. E., Grimshaw, H. M., Parkinson, J. A., Quamby, C., \& Roberts, J. D. (1986). Chemical analysis. In P. D. Moore \& S. B. Chapman (Eds.), Methods in plant ecology (pp. 285-344). Blackwell Scientific Publications, Oxford.

Awashthi, S. K. (2000). Central and State Rules as Amended for 1999: Prevention of Food Adulteration Act No. 37 of 1954.

BARC (Bangladesh Agricultural Research Council). (2012). Retrieved from http://www.barcapps.gov.bd/ documents/books/Fertilizer\%20Recommendation\%20Guide\%20-\%202012.pdf

Bhanarkar, A. D., Gajghate, D. G., \& Hasan, M. Z. (2002). Assessment of air pollution from small scale industry. Environmental Monitoring and Assessment, 80(2), 125-133. https://doi.org/10.1023/A:1020636930033

Bisht, G., \& Neupane, S. (2015). Impact of brick Kilns' emission on soil quality of agriculture fields in the vicinity of selected Bhaktapur Area of Nepal. Applied and Environmental Soil Science, 2015. https://doi.org/10.1155/2015/409401

Bray, R. H., \& Kurtz, L. T. (1945). Determination of total, organic, and available forms of phosphorus in soils. Soil Science, 59(1), 39-46. https://doi.org/10.1097/00010694-194501000-00006

Chen, S. B., Meng, W. A. N. G., Li, S. S., Zhao, Z. Q., \& Wen-di, E. (2018). Overview on current criteria for heavy metals and its hint for the revision of soil environmental quality standards in China. Journal of Integrative Agriculture, 17(4), 765-774. https://doi.org/10.1016/S2095-3119(17)61892-6

Day, P. R. (1965). Hydrometer method of particle size analysis. Methods of soil analysis: Part 1 Physical and Mineralogical Properties (Vol. 9, pp. 562-566). American Society of Agronomy, Madison, Wisconsin, USA.

De Temmerman, L. O., Hoenig, M., \& Scokart, P. O. (1984). Determination of "normal" levels and upper limit values of trace elements in soils. Zeitschrift für Pflanzenernährung und Bodenkunde, 147(6), 687-694. https://doi.org/10.1002/jpln.19841470606

Dey, S., \& Dey, M. (2017). Soil fertility loss and heavy metal accumulation in and around functional brick kilns in Cachar district, Assam, India: A multivariate analysis. Journal of Bio Innovation, 6(5), 768-781. 
Diatta, J., Grzebisz, W., Frackowiak-Pawlak, K., Andrzejewska, A., \& Brzykcy, M. (2014). Site-specific evaluation of $\mathrm{Cu}, \mathrm{Zn}, \mathrm{Fe}$ and $\mathrm{Mn}$ availability in arable soils. Zemdirbyste-Agriculture, 101(3), 235-242. https://doi.org/10.13080/z-a.2014.101.030

Epstein, E. (1965). Mineral metabolism. In J. Bonner, \& J. E. Varner (Eds.), Plant Biochemistry (pp. 438-466). Academic Press, London. https://doi.org/10.1016/B978-1-4832-3243-0.50022-8

Guo, W., Liu, X., Liu, Z., \& Li, G. (2010). Pollution and potential ecological risk evaluation of heavy metals in the sediments around Dongjiang Harbor, Tianjin. Procedia Environmental Sciences, 2, 729-736. https://doi.org/10.1016/j.proenv.2010.10.084

Hazelton, P., \& Murphy, B. (2016). Interpreting soil test results: What do all the numbers mean? CSIRO Publishing. https://doi.org/10.1071/9781486303977

Hossain, M. A., Zahid, A. M., Arifunnahar, M., \& Siddique, M. N. A. (2019). Effect of brick kiln on arable land degradation, environmental pollution and consequences on livelihood of Bangladesh. Journal of Science, Technology and Environment Informatics, 6(02), 474-488. https://doi.org/10.18801/jstei.060219.50

Huq, S. I., \& Alam, M. D. (2005). A handbook on analyses of soil, plant, and water (BACER-DU, No. 22, p. 246). University of Dhaka, Bangladesh.

Islam, M. S., \& Hoque, M. F. (2014). Concentrations of heavy metals in vegetables around the industrial area of Dhaka city, Bangladesh and health risk assessment. International Food Research Journal, 21(6). Retrieved from https://www.pstu.ac.bd/files/publications/1550804174.pdf

Islam, M. S., Ahmed, M. K., Habibullah-Al-Mamun, M., \& Hoque, M. F. (2015). Preliminary assessment of heavy metal contamination in surface sediments from a river in Bangladesh. Environmental Earth Sciences, 73(4), 1837-1848. https://doi.org/10.1007/s12665-014-3538-5

Ismail, M., Muhammad, D., Khan, F. U., Munsif, F., Ahmad, T., Ali, S., ... Ahmad, M. (2012). Effect of brick kilns emissions on heavy metal $(\mathrm{Cd}$ and $\mathrm{Cr})$ content of contiguous soil and plants. Sarhad Journal of Agriculture, 28(3), 403-409. Retrieved from https://www.aup.edu.pk/sj_pdf/EFFECT\%200F\%20BRIC K\%20KILNS\%20EMISSIONS\%20ON\%20HEAVY\%20METAL\%20-235-2010.pdf

Jackson, M. L. (1973). Soil chemical analysis. Prentice Hall of India Ltd., New Delhi.

Jiang, J. G., Xin, X. U., Jun, W. A. N. G., Yang, S. J., \& Zhang, Y. (2007). Investigation of basic properties of fly ash from urban waste incinerators in China. Journal of Environmental Sciences, 19(4), 458-463. https://doi.org/10.1016/S1001-0742(07)60076-X

Kabata-Pendias, A., \& Pendias, H. (1984). Trace elements in soil and plants (No. 631.41 K3). Boca Raton, FL: CRC.

Khan, H. R., Rahman, K., Rouf, A. A., Sattar, G. S., Oki, Y., \& Adachi, T. (2007b). Assessment of degradation of agricultural soils arising from brick burning in selected soil profiles. International Journal of Environmental Science and Technology, 4(4), 471-480. https://doi.org/10.1007/BF03325983

Khan, M. H., Rahman, M. K., Rouf, A. J. M. A., Sattar, G. S., Akhtar, M. S., Oki, Y., \& Adachi, T. (2007a). Effects of brick burning on microbial biomass and $\mathrm{C} / \mathrm{N}$ ratio in selected soil profiles in the eastern region of Bangladesh. Journal of the Faculty of Environmental Science and Technology, Okayama University, 12(1), 83-89. Retrieved from https://citeseerx.ist.psu.edu/viewdoc/download?doi=10.1.1.1069.4954\&rep=rep1\& type $=$ pdf

Kormoker, T., Proshad, R., Islam, S., Ahmed, S., Chandra, K., Uddin, M., \& Rahman, M. (2019). Toxic metals in agricultural soils near the industrial areas of Bangladesh: ecological and human health risk assessment. Toxin Reviews, 1-20. https://doi.org/10.1080/15569543.2019.1650777

Lindsay, W. L. (1979). Chemical equilibrium in soils. John Wiley and Sons, Inc., New York.

Moslehuddin, A. Z. M., Laizoo, S., \& Egashira, K. (1997). Fertility status of Bangladesh soils-A review. Journal Faculty of Agriculture Kyushu University, 41, 257-267. Retrieved from file://C:/Users/user/Downloads/ 10.1.1.956.5343\%file://C:/Users/user/Downloads/10.1.1.956.5343\%20(5).pdf20(5).pdf

Muller, G. (1969). Index of geoaccumulation in sediments of the Rhine river. Geojournal, 2, 108-118.

Murphy, J. A. M. E. S., \& Riley, J. P. (1962). A modified single solution method for the determination of phosphate in natural waters. Analytica Chimica Acta, 27, 31-36. https://doi.org/10.1016/S0003-2670 (00)88444-5 
Nelson, D. W., \& Sommers, L. (1983). Total carbon, organic carbon, and organic matter. In A. L. Page., R. H. Miller, \& D. R. Keeney (Eds.), Methods of soil analysis: Part 2 chemical and microbiological properties (pp. 539-579, Agronomy Monograph Vol 9). ASA and SSSA, Madison, WI. https://doi.org/10.2134/ agronmonogr9.2.2ed.c29

Rahman, U., Awan, M., Hassan, S., \& Khattak, M. (2000). Mosses as indicators of atmospheric pollution of trace metals $(\mathrm{Cd}, \mathrm{Cu}, \mathrm{Pb}, \mathrm{Mn}$ and $\mathrm{Zn})$ in the vicinity of coal-fired brick kilns in north-eastern suburbs of Islamabad, Pakistan. Journal of Radioanalytical and Nuclear Chemistry, 246(2), 331-336. https://doi.org/ 10.1023/A:1006782710160

Ravankhah, N., Mirzaei, R., \& Masoum, S. (2017). Determination of heavy metals in surface soils around the brick kilns in an arid region, Iran. Journal of Geochemical Exploration, 176, 91-99. https://doi.org/10.1016/ j.gexplo.2016.01.005

Sharma, N. K. (2000). Effect of air pollution emitted from brick kilns on growth performance and soil characteristics of some rabi and kharif crops. Pollution Research, 19(4), 657-659.

Sikder, A. H. F., Molla, M. D. H., Hossain, M. F., \& Parveen, Z. (2015). Lead and cadmium accumulation in nearby brick kiln Agri-environmental ecosystems. Bangladesh Journal of Scientific Research, 28(1), 51-59. https://doi.org/10.3329/bjsr.v28i1.26244

Skinder, B. M., Pandit, A. K., Sheikh, A. Q., \& Ganai, B. A. (2014). Brick kilns: Cause of atmospheric pollution. Journal of Pollution Effects and Control, 2(2). https://doi.org/10.4172/jpe.1000112

SRDI (Soil Resource Development Institute). (2008). Land and soil resource utilization guide (Vol. 91, No.18). Khulna Barisal Chittagong Divisions, Soil Resource Development Institute.

Ure, A. M. (1990). Methods of analysis of heavy metals in soils. In B. J. Alloway (Ed.), Heavy metals in soils (pp. 40-80). New York, John Wiley.

USDA (United States Department of Agriculture). Soil texture calculator. Retrieved from https://www.nrcs. usda.gov/wps/portal/nrcs/detail/soils/survey/?cid=nrcs142p2_054167

Vista, S. P., \& Gautam, B. (2018). Influence of brick processing on changes in soil physico-chemical properties of Bhaktapur District, Nepal. International Journal of Chemical Studies, 6(SP4), 146-150. Retrieved from https:/www.chemijournal.com/archives/2018/vol6issue4/PartD/SP-6-4-46-523.pdf

Yousaf, M., Li, J., Lu, J., Ren, T., Cong, R., Fahad, S., \& Li, X. (2017). Effects of fertilization on crop production and nutrient-supplying capacity under rice-oilseed rape rotation system. Scientific Reports, 7(1), 1-9. https://doi.org/10.1038/s41598-017-01412-0

Yu, S., Zhu, Y. G., \& Li, X. D. (2012). Trace metal contamination in urban soils of China. Science of the Total Environment, 421, 17-30. https://doi.org/10.1016/j.scitotenv.2011.04.020

Zhou, H., Yang, W. T., Zhou, X., Liu, L., Gu, J. F., Wang, W. L., ... Liao, B. H. (2016). Accumulation of heavy metals in vegetable species planted in contaminated soils and the health risk assessment. International Journal of Environmental Research and Public Health, 13(3), 289. https://doi.org/10.3390/ijerph13030289

\section{Copyrights}

Copyright for this article is retained by the author(s), with first publication rights granted to the journal.

This is an open-access article distributed under the terms and conditions of the Creative Commons Attribution license (http://creativecommons.org/licenses/by/4.0/). 